\title{
EFFECTS OF DIFFERENT PHOSPHORUS DOSES ON NUTRIENT CONCENTRATIONS AS WELL AS YIELD AND QUALITY CHARACTERISTICS OF LAVANDIN (Lavandula $\times$ intermedia Emeric ex Loisel. var. Super)
}

\author{
Sabri ERBAŞ ${ }^{1 *}$, Zeliha KUCUKYUMUK ${ }^{2}$, Hasan BAYDAR ${ }^{1}$, Ibrahim ERDAL ${ }^{2}$, Arif ŞANLI \\ ${ }^{1}$ Suleyman Demirel University, Faculty of Agriculture, Department of Field Crops, Isparta, TURKEY \\ ${ }^{2}$ Suleyman Demirel University, Faculty of Agriculture, Department of Soil Science and Nutrition, \\ Isparta, TURKEY \\ *Corresponding author: sabrierbas@sdu.edu.tr
}

Received: 18.04.2016

\begin{abstract}
Lavandin (Lavandula $\times$ intermedia Emeric ex Loisel. var. Super) is cultivated in an area of about 320 ha in Isparta province of Turkey. This study was conducted to determine the effects of phosphorus fertilization at the levels of $0,50,100$, and $150 \mathrm{~kg} \mathrm{ha}^{-1}$ on the yield characteristics, essential oil content and composition, and nutrient concentrations of lavandin (Lavandula $\times$ intermedia Emeric ex Loisel. var. Super) in 2010 and 2011 growing season. With an increase in the levels of phosphorus, the P, N, K, Ca and Fe concentrations increased in the leaves, while the $\mathrm{Mg}, \mathrm{Mn}$ and $\mathrm{Zn}$ concentrations $(\mathbf{p}<0.01)$ decreased. On the other hand, the characteristics of plant height, branch number, flower height and fresh, dry and drug flower yields increased up to the level of $100 \mathrm{~kg} \mathrm{ha}^{-1}$ of phosphorus but decreased at the higher level. In comparison with the control application, the application of $100 \mathrm{~kg} \mathrm{ha}^{-1}$ of phosphorus increased the essential oil content approximately by $16 \%$. Linalyl acetate, the main component of the essential oil, rose from 25.07 to $30.72 \%$ on average from the control application to the highest phosphorus application, whereas the rate of linalool decreased from 41.82 to $38.54 \%$. Phosphorus fertilization significantly affected the nutrient contents as well as yield and quality characteristics of lavandin. Therefore, application of $100 \mathrm{~kg} \mathrm{ha}^{-1}$ of phosphorus may be suggested in lavandin to obtain the ideal yield and quality.
\end{abstract}

Keywords: P fertilization, lavandin, yield, quality, nutrients.

\section{INTRODUCTION}

Lavender (Lavandula sp.), a valuable essential oil plant of family Lamiaceae, has about 25 species, most of which are of Mediterranean origin (Guenther 1952). It is most distributed in Southern Europe and in the North African countries neighboring the Mediterranean Sea in the world (Weiss 1997). There are three important lavender species with a high commercial value in the world (Tucker 1985): Lavender (Lavandula angustifolia $=$ L. officinalis $=L$. vera $)$, Lavandin $(L$. angustifolia $\times L$. latifolia $=$ Lavandula $\times$ intermedia $=$ L. hybrida $)$, and Spike lavender (Lavandula spica $=$ L. latifolia) . Like other plants of Lavandula species, lavandin is mostly used as essential oils for perfumery, cosmetics, flavoring, and pharmaceutical industries thanks to its essential oil content and composition. Lavandin oil is commonly blended, either with lavender oil or other commercial essential oils, to create a pleasing fragrance (Lawrence 1993; Harborne and Williams 2002). Lavandin cultivars produce significantly higher oil yield as compared to the lavender cultivars, and linalool and linalyl acetate are the main components of lavandin and lavender oils (Marotti et al. 1989; Renaud et al. 2001). The essential oil of lavender is one of the 15 most produced essential oils in the world. About 200 tons of lavender oil and 1200 tons of lavandin oil are annually produced in the world (Karapandzova et al. 2012).

Lavender is densely cultivated in France, Bulgaria, Spain, Italy, Greece, England, Russia, the USA, Austria, and the North African countries worldwide (Tucker 1985). In Turkey, it is most cultivated in Keçiborlu district of Isparta province. Lavender has very well adapted particularly to the non-irrigated, arid, and sloping lands of this locality. The agriculture of lavender (Lavandula $\times$ intermedia var. Super) in the region, which commenced in 1970, has now reached a production area of about 320 ha. Lavandin plants start flowering in early July after the flowering season of oil-bearing rose (Rosa damascena Mill.), and they are generally harvested in the second half of July. Some of the fresh cut flowers are distilled and 
utilized in the production of lavandin oil at some rose oil factories, whereas some of them are dried and utilized as dry flowers. 3500 to $5000 \mathrm{~kg}$ of fresh flowers per hectare are obtained on average, and 750 to $1000 \mathrm{~kg}$ per ha of dry flowers are obtained on average by drying the fresh flowers and separating them from their stems. Of bunches of dried stemmed flowers, $65 \%$ comprise stems and $35 \%$ are comprised of flowers (Baydar 2016). About $1 \mathrm{~kg}$ of essential oil is obtained through the steam distillation of from 50 to $75 \mathrm{~kg}$ of fresh lavandin flowers at the factories. The fresh lavandin flowers contain 1.5 to $2.5 \%$ light yellow essential oil, while its dry flowers contain 5 to $6 \%$ light yellow essential oil (Erbaş and Baydar 2008). The main essential oil components in the lavandin oil are linalyl acetate (20 to $30 \%$ ) and linalool (30 to $45 \%$ ) (LisBalchin 2002; Woronuk et al. 2011).

Many factors such as growing conditions, climatic conditions, the growth period of plants, and agricultural practices are effective on herb yield, drug yield, and essential oil content and composition in aromatic plants, along with genetic modifications (Lawrence 1993; Perry et al. 1999; Grausgruber-Gröger et al. 2012). Of agricultural practices, especially the application of phosphorus is a nutrient with an important role in the essential oil synthesis and assimilation in aromatic plants. Farnesyl diphosphate compresses to geranyl diphosphate and linalool diphosphate, and these components are precursors of essential oil production (Ramezani et al. 2009). Although it was reported that the essential oil content and yield were increased with the application of phosphorus in such aromatic plants as cumin, fennel, sage, oregano, basil, and coriander (Tunçturk and Tunçturk 2006; Moslemi et al. 2012; Nell et al. 2009; Meena et al. 2015), only the effect of application of foliar phosphorus on yield and quality was examined in lavender by Hussein et al. (1996) whose reported that application of $1 \%$ phosphorus twice before flowering might be suggested to increase the essential oil content and the flower yield. The present study aims to investigate the influence of phosphorus (P) fertilization on yield and quality characteristics as well as the nutrient concentrations of lavandin under field conditions.

\section{MATERIALS AND METHODS}

In the study, lavandin (Lavandula $\times$ intermedia Emeric ex Loisel. var. Super) was used as the material plant. The study was carried out in a trial field located at the Department of Field Crops, Faculty of Agriculture, Suleyman Demirel University, Isparta (latitude $37^{\circ} 47^{\prime} \mathrm{N}$, longitude $30^{\circ} 30^{\prime} \mathrm{E}$, elevation $1122 \mathrm{~m}$ ) in the 2010-2011 growing season. The soil of the research field was loamy in texture with pH 7.9 (1:2.5 water extract), $19 \% \mathrm{CaCO}_{3}$, and $1.7 \%$ organic matter (Jackson 1973). Extractable P $\left(0.5 \mathrm{M} \mathrm{NaHCO}_{3}^{-}\right)$was $30 \mathrm{~kg} \mathrm{ha}^{-1}$ and exchangeable $\mathrm{K}$ $\left(\mathrm{NH}_{4} \mathrm{OAC}^{-}\right.$) was $600 \mathrm{~kg} \mathrm{ha}^{-1}$ (Olsen et al. 1954; Knudsen et al. 1982). The DTPA extractable $\mathrm{Fe}, \mathrm{Zn}$ and $\mathrm{Mn}$ concentrations in leaves were $3.0,0.7$, and $4.4 \mathrm{mg} \mathrm{kg}^{-1}$, respectively. The climatic data for the research area are given in Table 1.

Table 1. Total precipitation, mean humidity and mean temperatures values of research area

\begin{tabular}{lccccccccc}
\hline \multirow{2}{*}{ Month } & \multicolumn{3}{c}{ Precipitation, $\mathbf{~ m ~}^{\mathbf{2}}$} & \multicolumn{3}{c}{ Mean temperature, ${ }^{\mathbf{O}} \mathbf{C}$} & \multicolumn{3}{c}{ Mean humidity, \% } \\
\cline { 2 - 9 } & $\mathbf{1 9 7 0 - 2 0 1 1}$ & $\mathbf{2 0 1 0}$ & $\mathbf{2 0 1 1}$ & $\mathbf{1 9 7 0 - 2 0 1 1}$ & $\mathbf{2 0 1 0}$ & $\mathbf{2 0 1 1}$ & $\mathbf{1 9 7 0 - 2 0 1 1}$ & $\mathbf{2 0 1 0}$ & $\mathbf{2 0 1 1}$ \\
\hline January & 76.7 & 68.0 & 34.6 & 2.1 & 4.2 & 2.9 & 75.0 & 76.9 & 78.2 \\
February & 69.2 & 136.8 & 51.8 & 3.1 & 5.7 & 3.7 & 67.0 & 75.3 & 75.6 \\
March & 63.2 & 33.2 & 50.4 & 6.8 & 8.7 & 6.3 & 52.1 & 59.6 & 70.2 \\
April & 60.0 & 47.0 & 42.8 & 11.7 & 11.9 & 10.3 & 56.3 & 61.0 & 68.5 \\
May & 47.7 & 32.4 & 42.5 & 16.5 & 17.1 & 14.4 & 46.3 & 55.1 & 64.8 \\
June & 31.0 & 64.5 & 61.8 & 21.1 & 19.2 & 19.8 & 28.7 & 61.8 & 56.6 \\
July & 17.0 & 40.1 & 1.8 & 24.3 & 24.8 & 25.0 & 12.6 & 49.0 & 42.3 \\
August & 16.2 & 0.2 & 0.6 & 24.0 & 27.0 & 22.9 & 12.5 & 38.0 & 40.7 \\
September & 25.2 & 15.7 & 14.8 & 19.9 & 20.7 & 18.3 & 49.9 & 52.2 & 51.6 \\
October & 57.4 & 79.1 & 31.4 & 14.4 & 12.7 & 12.8 & 64.8 & 70.2 & 65.9 \\
November & 72.9 & 13.6 & 0.2 & 8.4 & 10.8 & 0.4 & 63.2 & 64.6 & 54.5 \\
December & 87.7 & 84.2 & 4.2 & 4.1 & 6.8 & 2.5 & 75.1 & 80.1 & 66.7 \\
\hline
\end{tabular}

*Turkish State Meteorological Service

Propagation of plants was normally accomplished by taking cuttings on 15 March 2007. The cuttings were planted at 1-meter plant spacing and 1.5-meter row spacing. The plot length was $10 \mathrm{~m}$, and each plot contained 5 rows. Individual plots (50 plants) were $10 \times 1.5 \times 5=75 \mathrm{~m}^{2}$. In order to determine the effects of $\mathrm{P}$ on the yield and quality parameters of lavandin, four levels of $\mathrm{P}\left(0,50,100\right.$, and $\left.150 \mathrm{~kg} \mathrm{ha}^{-1}\right)$ were applied as triple superphosphate $\left(42 \% \mathrm{P}_{2} \mathrm{O}_{5}\right)$ in March for both years. Fertilization was performed in the form of a surface application in the lines and then mixed by means of a hoe.
No other fertilization was performed in the trial field and drip irrigation was applied when needed, between 20072010 years. Lavandin flowers were harvested by hand on 15 July 2010 and 17 July 2011. The characteristics under examination were determined using 10 randomly selected plants. The following observations were made: plant height $(\mathrm{cm})$, branch height $(\mathrm{cm})$, flower height $(\mathrm{cm})$, floret number per flower, fresh flower yield $\left(\mathrm{kg} \mathrm{ha}^{-1}\right)$, dry flower yield $\left(\mathrm{kg} \mathrm{ha}^{-1}\right)$, drug flower yield $\left(\mathrm{kg} \mathrm{ha}^{-1}\right)$, essential oil content (\%), and essential oil composition (\%). 
To make a nutrient analysis, leaf samples were collected from the middle of the shoots at the beginning of the flowering periods (Özcan 2004). Later on, the samples were washed thoroughly with tap water, dilute acid $(0.2 \mathrm{~N}$ $\mathrm{HCl}$ ), and distilled water to remove surface residues and then kept at $65 \pm 5{ }^{\circ} \mathrm{C}$ until they reached a stable weight. Afterwards, the leaf samples were dried and ground. The phosphorus concentrations of the samples were determined by means of a spectrophotometer (Shimadzu UV-1208) at $430 \mathrm{~nm}$ according to the vanadomolybdophosphoric acid method. The nitrogen concentrations of the samples were determined according to the Kjeldahl methods. Other nutrients such as $\mathrm{K}, \mathrm{Ca}$, $\mathrm{Mg}, \mathrm{Mn}, \mathrm{Fe}$, and $\mathrm{Zn}$ concentrations were determined using an atomic absorption spectrophotometer (Jones et al. 1991).

The essential oils of fresh flowers (100 g) were extracted by distillation for 3 hours under continuous steam using a neo-Clevenger apparatus according to the standard procedure described in European Pharmacopoeia (1975) so as to determine the oil content (\% v/w). After the oils had been dried over anhydrous sodium sulphate, they were stored at $4{ }^{\circ} \mathrm{C}$ until they were used for gas chromatography-mass spectrometry (GC-MS) analyses. The oil samples were weighed $(7.5 \mathrm{mg})$ and diluted in 1.5 $\mathrm{mL}$ of dichloromethane, and $1 \mu \mathrm{L}$ of this sample was injected into GC-MS, and the constituents of the oil samples were detected. The GC-MS analysis was performed on QP5050 GC-MS equipped with a Quadrapole detector. The GC-MS analysis was carried out as follows: capillary column, CPWax $52 \mathrm{CB}(50 \mathrm{~m} \times 0.32$ $\mathrm{mm}$ i.d., film thickness, $0.25 \mu \mathrm{m})$; oven temperature was kept at $60{ }^{\circ} \mathrm{C}$ for $10 \mathrm{~min}$ and programmed to $220^{\circ} \mathrm{C}$ at a rate of $10{ }^{\circ} \mathrm{C} \mathrm{min}^{-1}$, and then kept constant at $220{ }^{\circ} \mathrm{C}$ for $10 \mathrm{~min}$; total run time, $60 \mathrm{~min}$; injector temperature, 240 ${ }^{\circ} \mathrm{C}$; detector temperature, $250{ }^{\circ} \mathrm{C}$; and flow rate for

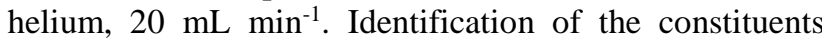
was carried out by the help of the retention times of standard substances by composition of mass spectra with the data given in the NIST library (Stein 1990) and our created library.

The results obtained in the two years were evaluated both individually and in combined form according to the randomized complete block design with three replications. All data were analyzed with the analysis of variance
(ANOVA) using GLM producers of SAS (1999) program, and the differences among treatments were compared with the LSD test $(\mathrm{p}<0.05)$.

\section{RESULTS AND DISCUSSION}

The effect of $\mathrm{P}$ application on nutrient concentrations

According to the results obtained, it was seen that $\mathrm{P}$ doses significantly affected leaf $\mathrm{P}$ concentrations for both years $(\mathrm{p}<0.01)$. As seen from Table 2 , the highest $P$ concentrations were determined at the highest $\mathrm{P}$ doses for both years. When compared with the control application, increases in leaf $\mathrm{P}$ concentrations were approximately by $40.9 \%$ in the first year and $59.1 \%$ in the second year. Similar results can be seen when the averages of both years are considered. This could be due to the increases in the available $\mathrm{P}$ concentrations in the root zone of the plant. Although the amount of soil $\mathrm{P}$ concentration seems to be sufficient, the application of high available $\mathrm{P}$ containing fertilizers to the soil can increase the plant nutrient concentrations (Nell et al. 2009; Rahimi et al. 2013; Khalid 2012, 2015; Kumar et al. 2015).

The plant nutrient concentrations did not vary by year, and the average values of leaf $\mathrm{N}$ concentrations significantly increased depending on the $\mathrm{P}$ application doses $(\mathrm{p}<0.01)$. While the lowest $\mathrm{N}$ value $(1.44 \%)$ was determined in the control (0) treatment, the highest value $(1.56 \%)$ was obtained from the highest $\mathrm{P}$ doses according to the two-year average (Table 2). The increases in the $\mathrm{N}$ concentration of the plants with the $\mathrm{P}$ applications might be related to better shoot and root growth (Sharma et al. 2008). In our study, it might have resulted from the overall improvement seen in the growth and development of the plant depending on the increase in the plant biomass in the lavandins treated with phosphorus.

Whilst the effect of application of phosphorus on the $\mathrm{K}$ concentration of lavandin was insignificant by year, the $\mathrm{K}$ concentration of the plants increased with an increase in the level of $\mathrm{P}$ according to the average of the 2 years $(\mathrm{p}<0.01)$. Based on the two-year average, the $\mathrm{K}$ concentration detected to be $2.01 \%$ in the plants in the control (0) group rose to $2.63 \%$ in the highest $\mathrm{P}$ application. Khalid (2012) reported that phosphorus fertilization significantly increased the $\mathrm{K}$ concentration in anise, coriander, and fennel.

Table 2. The effect of phosphorus treatment on nutrition concentrations in lavandin leaves

\begin{tabular}{|c|c|c|c|c|c|c|c|c|c|c|c|c|}
\hline \multirow{2}{*}{$\begin{array}{l}\text { P levels } \\
\left(\mathrm{kg} \mathrm{ha}^{-1}\right)\end{array}$} & \multicolumn{3}{|c|}{$\mathbf{P}(\%)$} & \multicolumn{3}{|c|}{$\mathbf{N}(\%)$} & \multicolumn{3}{|c|}{ K $(\%)$} & \multicolumn{3}{|c|}{$\mathrm{Ca}(\%)$} \\
\hline & $2010 * *$ & $2011 * *$ & Mean ** & 2010 & 2011 & Mean ** & 2010 & 2011 & Mean ** & $2010 * *$ & $2011 * *$ & Mean ** \\
\hline 0 & $0.22 \mathrm{c}$ & $0.22 \mathrm{~b}$ & $0.22 \mathrm{C}$ & 1.44 & 1.45 & $1.44 \mathrm{C}$ & 1.73 & 2.30 & $2.01 \mathrm{~B}$ & $0.58 \mathrm{c}$ & $0.59 \mathrm{c}$ & $0.58 \mathrm{C}$ \\
\hline 50 & $0.27 \mathrm{~b}$ & $0.25 \mathrm{~b}$ & $0.26 \mathrm{~B}$ & 1.48 & 1.50 & $1.49 \mathrm{BC}$ & 1.80 & 2.46 & $2.12 \mathrm{AB}$ & $0.82 \mathrm{~b}$ & $0.57 \mathrm{c}$ & $0.69 \mathrm{BC}$ \\
\hline 100 & $0.27 \mathrm{~b}$ & $0.26 \mathrm{~b}$ & $0.27 \mathrm{~B}$ & 1.57 & 1.50 & $1.53 \mathrm{AB}$ & 1.80 & 2.63 & $2.21 \mathrm{AB}$ & $0.85 \mathrm{~b}$ & $0.76 \mathrm{~b}$ & $0.80 \mathrm{~B}$ \\
\hline 150 & $0.31 \mathrm{a}$ & $0.35 \mathrm{a}$ & $0.33 \mathrm{~A}$ & 1.62 & 1.51 & $1.56 \mathrm{~A}$ & 2.03 & 2.50 & $2.63 \mathrm{~A}$ & $1.17 \mathrm{a}$ & $0.95 \mathrm{a}$ & $1.06 \mathrm{~A}$ \\
\hline \multirow{2}{*}{$\begin{array}{l}\text { P levels } \\
\left(\mathrm{kg} \mathrm{ha}^{-1}\right)\end{array}$} & \multicolumn{3}{|c|}{$\operatorname{Mg}(\%)$} & \multicolumn{3}{|c|}{$\operatorname{Mn}\left(\mathrm{mg} \mathrm{kg}^{-1}\right)$} & \multicolumn{3}{|c|}{ Fe $\left(\mathrm{mg} \mathrm{kg}^{-1}\right)$} & \multicolumn{3}{|c|}{$\mathbf{Z n}\left(\mathrm{mg} \mathrm{kg}^{-1}\right)$} \\
\hline & $2010 * *$ & 2011 & Mean ** & $2010 * *$ & 2011 & Mean ** & $2010 * *$ & $2011 * *$ & Means ** & 2010 & $2011 *$ & Mean ** \\
\hline 0 & $0.35 \mathrm{c}$ & 0.31 & $0.33 \mathrm{C}$ & $34.7 \mathrm{bc}$ & 24.0 & $29.4 \mathrm{C}$ & $104.7 \mathrm{c}$ & $112.0 \mathrm{~b}$ & $108.3 \mathrm{D}$ & 17.3 & $19.3 \mathrm{a}$ & $18.4 \mathrm{~A}$ \\
\hline 50 & $0.52 \mathrm{a}$ & 0.35 & $0.43 \mathrm{~A}$ & $45.0 \mathrm{a}$ & 26.0 & $35.4 \mathrm{~A}$ & $116.7 \mathrm{bc}$ & $120.3 \mathrm{~b}$ & $118.5 \mathrm{C}$ & 14.5 & $16.3 \mathrm{~b}$ & $15.4 \mathrm{~B}$ \\
\hline 100 & $0.41 \mathrm{~b}$ & 0.33 & $0.37 \mathrm{~B}$ & $38.3 \mathrm{~b}$ & 26.3 & $32.5 \mathrm{~B}$ & $123.3 \mathrm{~b}$ & $122.0 \mathrm{~b}$ & $122.6 \mathrm{~B}$ & 16.6 & $16.3 \mathrm{~b}$ & $16.5 \mathrm{~B}$ \\
\hline 150 & $0.41 \mathrm{~b}$ & 0.31 & $0.36 \mathrm{BC}$ & $32.7 \mathrm{c}$ & 24.7 & $28.5 \mathrm{C}$ & $143.7 \mathrm{a}$ & $142.0 \mathrm{a}$ & $142.9 \mathrm{~A}$ & 16.0 & $16.3 \mathrm{~b}$ & $16.2 \mathrm{~B}$ \\
\hline
\end{tabular}

Means with identical letters in the same column are not statistically significant; ${ }^{*} \mathrm{p}<0.05 ; * * \mathrm{p}<0.01$ 
The $\mathrm{Ca}$ and $\mathrm{Fe}$ concentrations of the plants significantly differed in both years depending on the $\mathrm{P}$ application $(\mathrm{p}<0.01)$. While the $\mathrm{Ca}$ and $\mathrm{Fe}$ concentrations of the plants were $0.58 \%$ and $108.3 \mathrm{mg} \mathrm{kg}^{-1}$ on average in the control application, they rose to $1.06 \%$ and $142.9 \mathrm{mg}$ $\mathrm{kg}^{-1}$ in the highest phosphorus application. The $\mathrm{P}$ application showed significant effects on the $\mathrm{Mg}$ and $\mathrm{Mn}$ contents of the plants in 2010 and according to the average of both years $(\mathrm{p}<0.01)$. The highest $\mathrm{Mg}$ and $\mathrm{Mn}$ concentrations were found at $50 \mathrm{~kg} \mathrm{ha}^{-1}$ in 2010 , whereas the lowest values were detected in the control application. The $\mathrm{Mg}$ and $\mathrm{Mn}$ concentrations of the plants were observed to have decreased at the higher doses. This might have been because the $\mathrm{K}$ concentration in the plants increased depending on the increased phosphorus dose and $\mathrm{K}$ caused toxicity, thereby reducing the $\mathrm{Mg}$ and $\mathrm{Mn}$ uptake (Heenan and Campbell 1981).

Similarly, the differences in the $\mathrm{Zn}$ concentrations of the plants were found significant in 2011 and according to the average of both years. The $\mathrm{Zn}$ concentration in the plants decreased to 16.2 from 18.4 with an increase in the dose of phosphorus according to the average of both years. This is due to the antagonistic effect between phosphorus and zinc. Even though a similar case is also reported in the plants of Trachyspermum ammi L. (ElWahab and Mohammed 2007) and Trachyspermum cucumeria L. (Karthikeyan et al 2008), there is no information on this subject concerning lavender. Only Hussein et al. (1996) reported that the application of foliar phosphorus to Lavandula angustifolia positively affected the uptake of such macronutrients as N, P, and K.

\section{The effect of $P$ application on yield and quality characteristics}

When the agronomic and quality characteristics were examined, it was seen that the application of phosphorus significantly affected plant height, the flower height, fresh, dry, and drug flower yields, and the essential oil content in 2010 and 2011 as well as according to the average of both years. Nevertheless, the differences in branch height were not significant in 2010, but significant in 2011 and according to the average of both years. The number of flower spikes of the plants was statistically insignificant. All characteristics were positively affected from the control application to the application of $100 \mathrm{~kg}$ $\mathrm{ha}^{-1}$ of phosphorus, whereas the characteristics were negatively affected at the higher dose. According to the phosphorus doses, the plant height, the branch height and the flower height were $92.6 \mathrm{~cm}, 47.2 \mathrm{~cm}$, and $10.5 \mathrm{~cm}$ on average in the control application, respectively, while the highest values of these characteristics were recorded as $104.3,53.0$, and $15.7 \mathrm{~cm}$ with the application of $100 \mathrm{~kg}$ $\mathrm{ha}^{-1}$ of phosphorus, respectively (Table 3 ). In the results obtained from our study, the increase in the phosphorus dose up to the dose of $100 \mathrm{~kg} \mathrm{ha}^{-1}$ was observed to have improved such characteristics as the flower length and the number of florets in plants. The $\mathrm{P}$ found at a limited level in soil is reported to slow down the development of the floral structures of plants (Ma et al. 2001). However, the $\mathrm{P}$ application enables the flowers to reach the maximum size but does not increase the number of flowers. This was also observed in the flowers of Calendula officinalis and Pimpinella anisum (Steward and Lovett-Doust 2003; Meena et al. 2015).

The $\mathrm{P}$ application had a positive effect on the fresh flower yield, dry flower yield, and drug flower yield of lavandin up to the dose of $100 \mathrm{~kg} \mathrm{ha}^{-1}$. The highest fresh and dry flower yields were obtained in 2011. The mean fresh flower yield ranged from 7520 to $11390 \mathrm{~kg} \mathrm{ha}^{-1}$, the dry flower yield from 3216 to $5022 \mathrm{~kg} \mathrm{ha}^{-1}$, and the drug flower yield from 1513 to $2357 \mathrm{~kg} \mathrm{ha}^{-1}$. The highest fresh, dry and drug flower yields were obtained from the application of $100 \mathrm{~kg} \mathrm{ha}^{-1}$ of $\mathrm{P}$ (Table 3). Given the nutrient uptake by the plants, the increase in yield characteristics is an expected case. Likewise, phosphorus is an element which is directly related to photosynthesis. It affects many metabolic events primarily such as chlorophyll, protein, carbohydrate, and oil syntheses, thereby contributing to the increase in yield. It is reported that phosphorus fertilization increases the chlorophyll content (Rathore et al. 1985; Ramezani et al. 2009) and the leaf area index (Maurya 1989) in basil and African marigold. Khalid (2012) reported that phosphorus fertilization in some Apiaceae (Umbelliferaceae) species increased total carbohydrate, total soluble sugar, total oil, and the vegetative productivity of plants. Similar results were also found in chamomile (Naderidarbaghshahi et al. 2011), feverfew (Saharkhiz and Omidbaigi 2008), sweet basil (Sharafzadeh et al. 2011), marigold (Ahmad et al. 2011), indigenous mint (Alsafar and Al-Hassan 2009), and sage (Lu et al. 2013).

Table 3. The effect of phosphorus treatment on yield and quality characters in lavandin

\begin{tabular}{|c|c|c|c|c|c|c|c|c|c|c|c|c|}
\hline \multirow[t]{2}{*}{$\begin{array}{l}\text { P levels } \\
\left(\text { kg ha }^{-1}\right)\end{array}$} & \multicolumn{3}{|c|}{ Plant height $(\mathrm{cm})$} & \multicolumn{3}{|c|}{ Branch height $(\mathrm{cm})$} & \multicolumn{3}{|c|}{ Flower height $(\mathrm{cm})$} & \multicolumn{3}{|c|}{ Floret number per flower } \\
\hline & $2010 *$ & $2011 * *$ & Mean ** & 2010 & $2011 *$ & Mean ** & $2010 * *$ & $2011 * *$ & Mean ** & 2010 & 2011 & Mean \\
\hline 0 & $92.2 \mathrm{c}$ & $93.0 \mathrm{~b}$ & $92.6 \mathrm{~B}$ & 46.2 & $48.3 \mathrm{~b}$ & $47.2 \mathrm{C}$ & $10.7 \mathrm{c}$ & $10.3 \mathrm{~b}$ & $10.5 \mathrm{C}$ & 8.6 & 8.5 & 8.6 \\
\hline 50 & $100.3 \mathrm{ab}$ & $101.9 \mathrm{a}$ & $101.1 \mathrm{~A}$ & 50.6 & $49.9 \mathrm{~b}$ & $50.3 \mathrm{AB}$ & $13.6 \mathrm{~b}$ & $13.8 \mathrm{a}$ & $13.7 \mathrm{~B}$ & 8.6 & 8.7 & 8.7 \\
\hline 100 & $104.0 \mathrm{a}$ & $104.7 \mathrm{a}$ & $104.3 \mathrm{~A}$ & 51.7 & $54.3 \mathrm{a}$ & $53.0 \mathrm{~A}$ & $15.7 \mathrm{a}$ & $15.7 \mathrm{a}$ & $15.7 \mathrm{~A}$ & 8.7 & 8.7 & 8.7 \\
\hline 150 & $96.5 \mathrm{bc}$ & $94.3 \mathrm{~b}$ & $95.4 \mathrm{~B}$ & 48.3 & $47.6 \mathrm{~b}$ & $47.9 \mathrm{BC}$ & $10.4 \mathrm{c}$ & $11.3 \mathrm{~b}$ & $10.9 \mathrm{C}$ & 8.5 & 8.6 & 8.6 \\
\hline $\begin{array}{l}\text { P levels } \\
\left(\text { kg ha }^{-1}\right)\end{array}$ & \multicolumn{3}{|c|}{$\begin{array}{c}\text { Fresh flower yield } \\
\left(\mathrm{kg} \mathrm{ha}^{-1}\right)\end{array}$} & \multicolumn{3}{|c|}{$\begin{array}{l}\text { Dry flower yield } \\
\left(\mathrm{kg} \mathrm{h}^{-1}\right)\end{array}$} & \multicolumn{3}{|c|}{$\begin{array}{l}\text { Drug flower yield } \\
\left(\mathrm{kg} \mathrm{ha}^{-1}\right)\end{array}$} & \multicolumn{3}{|c|}{$\begin{array}{c}\text { Essential oil content } \\
(\%)\end{array}$} \\
\hline & $2010 * *$ & $2011 * *$ & Mean ** & 2010 ** & $2011 * *$ & Mean ** & $2010 * *$ & $2011 * *$ & Means ** & $2010 * *$ & $2011 * *$ & Mean ** \\
\hline 0 & $7669 \mathrm{c}$ & $7370 \mathrm{c}$ & $7520 \mathrm{D}$ & $3281 \mathrm{c}$ & $3152 \mathrm{c}$ & $3216 \mathrm{D}$ & $1544 \mathrm{c}$ & $1483 \mathrm{c}$ & $1513 \mathrm{C}$ & $1.80 \mathrm{c}$ & $1.80 \mathrm{~b}$ & $1.80 \mathrm{C}$ \\
\hline 50 & $8481 \mathrm{~b}$ & 8879 b & $8680 \mathrm{C}$ & $3778 \mathrm{~b}$ & $3940 \mathrm{~b}$ & $3864 \mathrm{C}$ & $1806 \mathrm{~b}$ & $1888 \mathrm{~b}$ & 1847 B & $1.96 \mathrm{~b}$ & $2.00 \mathrm{~b}$ & $1.97 \mathrm{~B}$ \\
\hline 100 & $10861 \mathrm{a}$ & $11920 \mathrm{a}$ & $11390 \mathrm{~A}$ & $4786 \mathrm{a}$ & $5258 \mathrm{a}$ & $5022 \mathrm{~A}$ & $2245 \mathrm{a}$ & $2469 \mathrm{a}$ & $2357 \mathrm{~A}$ & $2.09 \mathrm{a}$ & $2.10 \mathrm{a}$ & $2.10 \mathrm{~A}$ \\
\hline 150 & $9163 \mathrm{~b}$ & $9578 \mathrm{~b}$ & $9371 \mathrm{~B}$ & $4076 \mathrm{~b}$ & $4258 \mathrm{~b}$ & $4167 \mathrm{~B}$ & $1845 \mathrm{~b}$ & $1927 \mathrm{~b}$ & $1886 \mathrm{~B}$ & $2.02 \mathrm{a}$ & $2.09 \mathrm{a}$ & $2.06 \mathrm{~A}$ \\
\hline
\end{tabular}


The essential oil content of lavandin flowers significantly increased with phosphorus fertilization. Whilst the essential oil content in the unfertilized plants was determined as $1.80 \%$ on average, the essential oil content increased up to the application of $100 \mathrm{~kg} \mathrm{ha}^{-1}$ of $\mathrm{P}$ and rose to $2.10 \%$ on average. On the other hand, it decreased to $2.06 \%$ in the application of $150 \mathrm{~kg} \mathrm{ha}^{-1}$ of $\mathrm{P}$. However, there is no statistical difference between these two applications (100 and $150 \mathrm{~kg} \mathrm{ha}^{-1}$ ) (Table 3) Phosphorus fertilization increased the essential oil content in the flowers. This might have been due to the increase in the synthesis of tricycle-glycerol from glycerol-3phosphate - the precursor to the syntheses of mevalonic acid and isoprene that constituted the building blocks of the essential oil. In addition, now that phosphorus makes up the building blocks of the phosphoenolpyruvate (PEP) molecule it plays a significant role in the formation of aromatic compounds (Qadry 2010). Our results are in agreement with Hussein et al. (1996), who reported that the essential oil content increased with the application of $1 \%$ foliar phosphorus in lavender. Although the rates of increase also differed in the plants belonging to different families, the application of phosphorus was observed to have had a positive effect on the essential oil content. The application of phosphorus increased the essential oil content in basil (Ramezani et al. 2009), chamomile (Nikolova et al. 1999), chrysanthemum (AlvarezCastellanus and Pascual-Villalobos 2003), fennel (Kapoor et al. 2004), cumin (Tuncturk and Tuncturk 2006), parsley (Kandeel 1991), coriander (Khalid 2015), and sage (Abaas 2014).

The averages concerning the effect of the $\mathrm{P}$ application on the essential oil composition of lavandin are presented in Table 4. The essential components of lavandin varied upon $\mathrm{P}$ fertilization in comparison with the control application. A total of 36 components were detected in the essential oil of lavandin; however, a total of 18 major components with total amounts ranging from 98.35 to $99.65 \%$ were evaluated. The rates of the 18 remaining micro components varied between 0.35 and $1.65 \%$. The oxygenated monoterpenes constituted the main group of the essential oil (92.25-93.86\%), followed by the monoterpene hydrocarbon group (3.07-3.76\%). On the other hand, ketone and esters ranged from 2.03 to $2.38 \%$ but sesquiterpene hydrocarbons from 0.34 to $0.52 \%$ in lavandin oil (Table 4). The fact that lavandin oil comprised the primary monoterpenes $\left(\mathrm{C}_{10}\right)$ was also reported by Lis-Balchin (2002). In the study, the main components of the essential oil of lavandin consisted of monoterpene compounds such as linalool $>$ linalyl acetate $>$ borneol $>\alpha$-terpineol $>$ geranyl acetate $>1,8$-cineole. The rate of linalool was $41.82 \%$ on average in the control application, whereas it decreased to $38.54 \%$ in the highest $\mathrm{P}$ application. On the other hand, the rate of linalyl acetate rose to $30.72 \%$ from $25.07 \%$ on average with the increased $\mathrm{P}$ application.

Table 4. The effect of phosphorus treatment on essential oil composition in lavandin

\begin{tabular}{|c|c|c|c|c|c|c|c|c|c|}
\hline \multirow{2}{*}{ Essential oil composition (\%) } & \multirow{2}{*}{$\begin{array}{l}\mathrm{RT}^{*} \\
(\mathbf{m i n})\end{array}$} & \multicolumn{2}{|c|}{0 kg ha $^{-1}$} & \multicolumn{2}{|c|}{$50 \mathrm{~kg} \mathrm{ha}^{-1}$} & \multicolumn{2}{|c|}{$100 \mathrm{~kg} \mathrm{ha}^{-1}$} & \multicolumn{2}{|c|}{$150 \mathrm{~kg} \mathrm{ha}^{-1}$} \\
\hline & & 2010 & 2011 & 2010 & 2011 & 2010 & 2011 & 2010 & 2011 \\
\hline Myrcene & 13.4 & 0.95 & 0.99 & 0.83 & 0.82 & 0.83 & 0.78 & 0.70 & 0.71 \\
\hline Limonene & 15.6 & 0.63 & 0.66 & 0.64 & 0.59 & 0.57 & 0.52 & 0.45 & 0.49 \\
\hline 1.8-cineole & 16.2 & 3.55 & 3.96 & 3.33 & 3.26 & 3.26 & 3.24 & 2.96 & 3.02 \\
\hline$p$-cymene & 17.2 & 2.18 & 2.08 & 2.04 & 1.95 & 2.00 & 1.85 & 2.00 & 1.87 \\
\hline 3-octanone & 18.8 & 0.64 & 0.70 & 0.68 & 0.70 & 0.50 & 0.62 & 0.51 & 0.49 \\
\hline Hexyl acetate & 19.5 & 0.66 & 0.64 & 0.63 & 0.59 & 0.57 & 0.55 & 0.56 & 0.55 \\
\hline 1-octen-3-yl acetate & 25.9 & 0.29 & 0.32 & 0.31 & 0.28 & 0.27 & 0.29 & 0.30 & 0.28 \\
\hline Hexyl butanoate & 28.4 & 0.72 & 0.72 & 0.68 & 0.65 & 0.70 & 0.66 & 0.76 & 0.71 \\
\hline Camphor & 35.8 & 4.48 & 4.66 & 3.45 & 4.01 & 4.36 & 4.45 & 4.42 & 4.31 \\
\hline Linalool & 36.7 & 42.19 & 41.45 & 40.48 & 39.00 & 39.68 & 39.45 & 38.56 & 38.52 \\
\hline Linalyl acetate & 37.4 & 24.87 & 25.26 & 25.84 & 26.41 & 29.78 & 28.13 & 30.94 & 30.50 \\
\hline Neryl acetate & 40.5 & 3.01 & 2.95 & 3.26 & 3.50 & 3.39 & 3.65 & 3.30 & 3.42 \\
\hline$\beta$-farnesene & 44.1 & 0.34 & 0.35 & 0.38 & 0.42 & 0.49 & 0.52 & 0.42 & 0.50 \\
\hline$\alpha$-terpineol & 46.6 & 4.04 & 4.41 & 3.86 & 3.99 & 3.15 & 3.68 & 3.87 & 4.00 \\
\hline Borneol & 46.7 & 3.61 & 3.90 & 5.29 & 5.42 & 3.84 & 4.00 & 3.90 & 4.12 \\
\hline Geranyl acetate & 47.9 & 4.10 & 4.15 & 3.90 & 4.12 & 3.40 & 3.62 & 3.51 & 3.65 \\
\hline Nerol & 52.0 & 0.70 & 0.50 & 0.68 & 0.52 & 0.53 & 0.53 & 0.77 & 0.67 \\
\hline Geraniol & 54.9 & 2.30 & 1.95 & 2.16 & 2.12 & 1.98 & 2.12 & 0.49 & 1.65 \\
\hline Monoterpene hydrocarbons & & 3.76 & 3.73 & 3.51 & 3.36 & 3.40 & 3.15 & 3.15 & 3.07 \\
\hline Oxygenated monoterpenes & & 92.85 & 93.19 & 92.25 & 92.35 & 93.37 & 92.87 & 92.72 & 93.86 \\
\hline Ketons and esters & & 2.31 & 2.38 & 2.30 & 2.22 & 2.04 & 2.12 & 2.13 & 2.03 \\
\hline Sesquiterpene hydrocarbons & & 0.34 & 0.35 & 0.38 & 0.42 & 0.49 & 0.52 & 0.42 & 0.50 \\
\hline
\end{tabular}


Similar to other terpenoids, these biochemicals with low molecular weights result from the condensation of isopentenyl diphosphate (IPP, $\mathrm{C}_{5}$ ) and dimethylallyl diphosphate (DMAPP, $\mathrm{C}_{5}$ ) - the universal terpene precursors. While monoterpenes are generally synthesized from geranyl diphosphate (GPP), sesquiterpenes are synthesized from farnesyl diphosphate (FPP) (Woronuk et al. 2011). Linalyl diphosphate is the precursor to the production of linalool. Linalyl acetate is modified by adding an acetyl CoA group to linalool (Zaks et al. 2008). In our study, the $\mathrm{P}$ application increased the synthesis of linalool from the GPP and the concentration of the acetyl CoA enzyme, one of whose building blocks was $\mathrm{P}$, and the rate of linalyl acetate might have increased upon the intensive catalyzation of these two molecules. With the P application, the myrcene, $p$-cymene, limonene, 1,8cineole, geranyl acetate and geraniol components of the essential oil relatively decreased, whereas its $\beta$-farnesene and neryl acetate contents increased, although slightly. On the other hand, the variations in 3-octane, hexyl acetate, 1octen-3-yl acetate, hexyl butanoate, camphor and nerol contents were unaffected by the levels of P. Borneol was higher at the first $\mathrm{P}$ application dose, but it was decreased at the other doses. $\alpha$-terpineol was decreased by $P$ application. Borneol and camphor are synthesized from bornyl diphosphate and contain phosphate in their structures. While the concentrations of borneol and camphor are expected to increase in reality like linalool and linalyl acetate, the presence of these compounds at a proportionately low concentration might cause the variations of increases and decreases to remain at a low level. Camphor is reported to range from 4 to $12 \%$ in lavandin oil and to reduce quality and the market value (Lawrence 1994; Lis-Balchin 2002). Similar results about the compounds found at low rates in our study were also obtained by Khalid (2015). Rioba et al. (2015) reported that the application of phosphorus in sage reduced the 1,8cineole content but did not affect the camphor or borneol content.

In the study, phosphorus fertilization significantly affected the nutrient contents as well as yield and quality characteristics of lavandin. The $\mathrm{P}$ application increased the $\mathrm{P}, \mathrm{N}, \mathrm{K}, \mathrm{Ca}$, and $\mathrm{Fe}$ concentrations in lavandin, and this increase was positively reflected in the yield characteristics of the plant and in its essential oil content and composition. All yield characteristics other than the floret number increased up to the level of $100 \mathrm{~kg} \mathrm{ha}^{-1}$ of P. Thus, $100 \mathrm{~kg} \mathrm{ha}^{-1}$ of $\mathrm{P}$ fertilization in lavandin will be useful to obtain the ideal yield and quality.

\section{LITERATURE CITED}

Abaas, I.S. 2014. The study of biometric and volatile oil quantity of sage plant (Salvia officinalis L.) as medicinal plant affected by nitrogen and phosphorus fertilizers. Int. J. Pharm. Pharm. Sci. 6(6):82-83.

Ahmad, I. M. Asif, A. Amjad and S. Ahmad 2011. Fertilization enhances growth, yield, and xanthophyll contents of marigold. Turk. J. Agric. For. 35:641-648.

Alsafar, M.S. and Y.M. Al-Hassan 2009. Effect of nitrogen and phosphorus fertilizers on growth and oil yield of Indigenous mint (Mentha longifolia L.). Biotechnology 8:380-384.
Alvarez-Castellanos, P.P. and M.J. Pascual-Villalobos 2003. Effect of fertilizer on yield and composition of flowerhead essential oil of Chrysanthemum coronarium (Asteraceae) cultivated in Spain. Ind. Crops Prod. 17:77-81.

Baydar, H. 2016. Medicinal and Aromatic Plants Sciences and Technology. $5^{\text {th }}$ Ed. Suleyman Demirel University, Press no: 51, (ISBN: 975-7929-79-4).

El-Wahab, A. and A. Mohammed 2007. Effect of nitrogen and magnesium fertilization on the production of Trachyspermum ammi L. (Ajowan) plants under Sinai conditions. J. Appl. Sci. Res. 3(8):781-786.

Erbaş S. and H. Baydar 2008. Effect of harvest time and drying temperature on essential oil content and composition in lavandin (Lavandula $\times$ intermedia Emeric ex Loisel.). TJFC 13(1):24-31.

European Pharmacopoeia, 1975. Maissonneuve Sainte Ruffine 3:68.

Grausgruber-Groger, S. C. Schmiderer, R. Steinborn and J. Novak 2012. Seasonal influence on gene expression of monoterpene syntheses in Salvia officinalis (Lamiaceae). J. Plant Physiol. 169:353-359.

Guenther, E. 1952. The essential oils, R.E. Krieger Pub. Co. 5:338 .

Harborne, J.B. and C Williams 2002. Phytochemistry of the genus Lavandula, in: Lavender, the genus Lavandula. Taylor \& Francis Inc, New York, NY 10001, ISBN 0-415-28486-4.

Hussein, M. E. El-Saeid and El-Sherbeny 1996. Yield and quality of lavender in relation to foliar application of sulfur and phosphorus. Egyptian J. Horticulture 23(2):167-178.

Jackson, M.L. 1973. Soil Chemical Analysis, Prentice-Hall, Inc., Englewood Cliffs, N.S.

Jones, J.J.B. B. Wolf and H.A. Mills 1991. Plant Analysis Handbook. Micro-Macro Publishing, Athens, Georgia, 30607, USA, $213 \mathrm{p}$.

Kandeel, A. 1991. Influence of soil and foliar nutrition on growth and volatile oil content of parsley (Petroselinum crispum Mill). Ann. Agric. Sci. 36(1):155-162.

Kapoor, R. B. Giri and K.G. Mukerji 2004. Improved growth and essential oil yield and quality in Foeniculum vulgare Mill. on mycorrhizal inoculation supplemented with Pfertilizer. Bioresource Technol. 93:307-311.

Karapandzova, M. I. Cvetkovikj, G. Stefkov, V. Stoimenov, M. Crvenov and S. Kulevanova 2012. The influence of duration of the distillation of fresh and dried flowers on the essential oil composition of lavandin cultivated in Republic of Macedonia. Macedonian Pharmaceutical Bulletin 58(1,2):3138 .

Karthikeyan, B. C.A. Jaleel, C.X. Zhao, M.J. Manoharan, J. Srimannarayan and M. Deiveekasundaram 2008. The effect of AM fungi and phosphoous leven on the biomass yield and ajmalicine production in Catharanthus roseus. EurAsia J. BioSci. 2:26-33

Khalid, K.A. 2012. Effect of phosphorous fertilization on anise, coriander and sweet fennel plants growing under arid region conditions. Med. Aromat. Plant. Sci. Biotechnol. 6(1):127131.

Khalid, K.A. 2015. Effect of macro and micro nutrients on essential oil of coriander fruits. JMES 6(8):2060-2065.

Knudsen, D. G.A. Peterson and P.F Pratt 1982. Lithium, sodium and potassium. methods of soil analysis, Part 2. Chemical and Microbiological Properties. Exchangeable Captions, 159-165.

Kumar, P. S.K Pandey and P. Kumar 2015. Effect of different phosphorus levels on nutrient content, uptake and economics of urdbean under custard apple based agri-horti system. J. AgriSearch 2(2):88-93. 
Heenan, D.P. and L.C. Campbell 1981. Influence of potassium and manganese on growth and uptake of magnesium by soybeans (Glycine $\max (\mathrm{L}$.$) Merr. cv. Bragg). Plant Soil$ (1981) 61: 447.

Lawrence, B.M. 1993. Progress in essential oils, lavender oils. Perf. Flav. 18(1):58-61.

Lawrence, B.M. 1994. Essential Oils. Allured Publ. Corp., Wheaton, IL.

Lis-Balchin, M. 2002. Lavender: The genus Lavandula. London: CRC Press, 208-209.

Lu, L. C. He, Y. Jin, Y. X. Zhang and J. Wei 2013. Effect of the applications of phosphorous and potassium fertilizers at different growth stage on the root growth and bioactive compounds of Salvia miltiorrhiza Bunge. Aust. J. Crop Sci. 7(10):1533-1543.

Ma, Q. N. Longnecker and C Atkins 2001. Varying phosphorous supplied and development, growth and seed yield in narrow leafed lupin. Plant and Soil 239:79-85.

Marotti, M. R. Piccaglia and C. Galletti 1989. Characterization of essential oils from Lavandula hybrida Rev. in Northern Italy. Herba Hungarica 28:37-44.

Maurya, K.R. 1989. Growth, yield and quality component in coriander genotypes. Indian Journal of Horticulture 46:107110.

Meena, R.L. S.S. Meena, R.S. Mehta, R.D. Meena and Saini 2015. Response of varying nitrogen and phosphorus levels on growth and yield of anise (Pimpinella anisum L.). Int. J. Seed Spices 5(1):83-87.

Moslemi, M., Aboutalebi, A., Hamed, A., Farah, H. 2012. Evaluation the effects of different levels of phosphorous on yield and yield components of coriander (Coriandrum sativum L.). World Applied Sciences Journal, 19(11):16211624.

Naderidarbaghshahi, M. S.M. Monemian H. Zeynali and B. Bahari 2011. Effects of different levels of nitrogen, phosphorus and potassium fertilizers on some agromorphological and biochemical traits of German chamomile (Matricaria chamomilla L.). J. Med. Plants Res. 6(2): 277283.

Nell, M. M. Votsch, H. Vierheilig, S. Steinkellner, K. ZitterlEglseer, C. Franz and J. Novak 2009. Effect of phosphorus uptake on growth and secondary metabolites of garden sage (Salvia officinalis L.). J. Sci. Food Agric. 89:1090-1096.

Nikolova, A. A.K. Kozhuharova, V.D. Zheljazkov and L.E. Craker 1999. Mineral nutrition of chamomile (Chamomilla recutita L.). Acta Horticulture 502:203208.

Olsen, S.R. V. Cole, F.S. Watanabe and L.A. Dean 1954. Estimations of available phosphorus in soils by extractions with sodium bicarbonate. U.S. Dept. of Agric. Cric. 939-941.

Özcan, M. 2004. Mineral contents of some plants used as condiments in Turkey. Food Chemistry 84:437-440.

Perry, N.B. R.E. Anderson, N.J. Brennan, M.H. Douglas, A.J. Heaney, J.A. McGimpsey and B.M. Smallfield 1999. Essential oils from Dalmatian sage (Salvia officinalis L.): variations among individuals, plant parts, seasons, and sites. J. Agric. Food Chem. 47:2048-2054.

Qadry, J.S. 2010. Pharmacognosy.16 ${ }^{\text {th }}$ Ed., Somya Printers. Delhi-5.
Rahimi M. M.R.A. Poor, F. Reza and M. Rahman 2013. Effects of potassium and phosphorus fertilizers on arsenic phytotoxicity and essential oil yield of two basil cultivars. BEPLS 2(5):86-92

Ramezani, S. M.R. Rezaei and P. Sotoudehnia 2009. Improved growth, yield and essential oil content of basil grown under different levels of phosphorus sprays in the field. J. Appl. Biol. Sci. 3(2):105-110.

Rathore, S.V.S. D.K. Dera and U. Chand 1985. Studies of nitrogen nutrition through foliar spray of urea on the performance of African marigold. Udyarika 5:37-40.

Renaud, E.N.C. D.J. Charles and J.E. Simon 2001. Essential oil quantity and composition from 10 cultivars of organically grown lavender and lavandin. J. Essential Oil Res. 13(4):269-273

Rioba, N.B. F.M. Itulya, M. Saidi, N. Dudai and N. Bernstein 2015. Effects of nitrogen, phosphorus and irrigation frequency on essential oil content and composition of sage (Salvia officinalis L.). J. Appl. Res. Med. Aromat. Plants 2:21-29.

Saharkhiz, M.J. R. Omidbaigi and F. Sefidkon 2007. The effect of phosphorus and arrigation treatments on the essential oil content and composition of feverfew (Tanacetum parthenium (L.) cv. Zardband). JEOBP 10(5):391-398.

SAS Institute, 1998. INC SAS/STAT User's Guide Release 7.0, Cary, NC, USA.

Sharafzadeh, S. M. Esmaeili and A.H. Mohammadi 2011. Interaction effects of nitrogen, phosphorus and potassium on growth, essence and total phenolic content of sweet basil. Adv. Environ. Biol. 5(6):1285-1289.

Sharma, R. S.S. Dahiya, M. Singh, R.K. Malik and D. Singh 2008. Effect of sulfur and phosphorus interactions on growth and nutrient content in green gram. Haryana Agric. Univ. J. Res. 38(1/2):41-77.

Stein, S.E. 1990. National Institute of Standards and Technology (NIST) Mass Spectral Database and Software, Version 3.02, Juen USA

Steward, C.L.S. and L. Lovett-Doust 2003. Effect of phosphorous treatment an growth and yield in the medicinal herbs Calendula officinalis L. (Standart Pasific) under hyproponic cultivation. Canadian J. Plant Sci. 4:611-617.

Tucker, A.O. 1985. Lavender, spike, and lavandin. The Herbarist 51:44-50.

Tuncturk, R. and M. Tuncturk 2006. Effects of different phosphorus levels on the yield and quality components of cumin (Cuminum cyminum L.). Res. J. Agric. Biol. Sci. 2:336-340.

Weiss, E.A. 1997. Essential Oil Crops. CAB International, New York, USA.

Woronuk, I.B. Z. Demissie, M. Rheault and S. Mahmoud 2011. Biosynthesis and therapeutic properties of Lavandula essential oil constituents. Planta Med 77:7-15.

Zaks, A. R.D. Rikanati, E. Bar, M. Inbar and E. Lewinsohn 2008. Biosynthesis of linalyl acetate and other terpenes in lemon mint (Mentha aquatica var. citrata, Lamiaceae) glandular trichomes. Isr. J. Plant Sci. 56:233-244. 